\title{
ALIENACÃO DO TRABALHO: despertencimento social e desrenraizamento em relação à natureza ${ }^{1}$
}

\author{
Tânia Franco *
}

\begin{abstract}
O ensaio resgata a noção de trabalho alienado, considerando o seu valor heurístico para compreender, mais profundamente, as interconexões entre os fundamentos do trabalho e os atuais desafios da crise social e ambiental. As atuais interrogações sobre o trabalho conduzem à abordagem da precarização social, da perda de direitos, dos danos à saúde e ao meio ambiente, evidências, por si só, de uma profunda alienação social. A partir de uma breve retrospectiva histórica das sociedades urbano-industriais capitalistas - em que se destaca o crescente desacordo dos tempos sociais com os ciclos da natureza e com a plasticidade ou limites biopsicossociais dos indivíduos -, propõe-se uma releitura dos quatro aspectos do conceito de alienação de Marx. As interligações entre alienação e o conceito bourdieusiano de habitus, entre precarização social e destruição ambiental são, por fim, sintetizadas nas noções de despertencimento social e de desenraizamento em relação à Natureza, processos característicos da civilização contemporânea.
\end{abstract}

PALAVRAS-CHAVE: trabalho alienado, trabalho e meio ambiente, trabalho e saúde, precarização do trabalho, flexibilização e precarização social.

\section{TRABALHO ALIENADO, SAÚDE E MEIO AMBIENTE: introdução}

"Conjurar a amnésia conceitual e teórica a fim de traçar precisamente as descontinuidades e as continuidades de nossas interrogações sobre o trabalho" (Mercure; Spurck, 2005, p.11).

Buscamos resgatar a noção de trabalho alienado, reconhecendo o valor heurístico dessa noção marxista para a construção de uma perspectiva teórica que incorpore a existência tanto dos limites biológicos, físicos e químicos da natureza quanto da plasticidade e limites biopsicossociais dos indivíduos como substrato da realidade social e, mais especificamente, do mundo do trabalho. Esses limites, frequentemente, permanecem como elementos exteriores ou

* Doutora em Ciências Sociais pela Universidade Federal da Bahia. Pesquisadora do Centro de Recursos Humanos/FFCH/UFBA. franctania@gmail.com Faculdade de Filosofia e Ciências Humanas. Estrada de São Lázaro, 197. Federação, Cep: 40.210-730. Salvador, Bahia-Brasil. franctania@gmail.com

${ }^{1}$ Agradeço os comentários e sugestões dos pareceristas e da editora, que só fizeram enriquecer a qualidade do texto e, em especial, a Luara Campos, aluna e bolsista de Iniciação Científica do curso de Ciências Sociais/FFCH/UFBA, por sua colaboração na revisão do artigo. acessórios nas análises sociológicas, restritos às abordagens funcionalistas e (ou) pulverizados em diferentes saberes disciplinares.

\begin{abstract}
No sentido em que lhe é dado por Marx, [alienação é a] ação pela qual (ou estado no qual) um indivíduo, um grupo, uma instituição ou uma sociedade se tornam (ou permanecem) alheios, estranhos, enfim, alienados [1] aos resultados ou produtos de sua própria atividade (e à atividade ela mesma), e/ou [2] à natureza na qual vivem, e/ ou [3] a outros seres humanos, e - além de, através de, [1], [2] e [3] - também [4] a si mesmos (às suas possibilidades humanas constituídas historicamente) Bottomore (2001, p.5).
\end{abstract}

As sociedades urbano-industriais efetivaram, ao longo de quatro séculos, uma completa revolução nas atividades humanas no trabalho, ao inverterem o arranjo trabalhador $\rightarrow$ instrumento $\rightarrow$ objeto, que prevalecia, até então, em diferentes contextos culturais, sob variadas formas de constrangimentos e de dominação. Nesse arranjo 'artesanal', o trabalhador, mediante os instrumentos ou tecnologias, atuava e modificava os objetos, imprimindo-lhes a sua ação, sua criatividade, sua vontade, seu savoir-faire. 
Desde o período da manufatura - impulsionada pelo mercantilismo - e do sistema fabril, a organização das empresas subverteu essa ordem primeva através das relações de dominação do capital, que inverteram o sentido do trabalho nesse arranjo. O instrumento ou tecnologia (surge como poder alheio e estranho) $\rightarrow$ (sob o qual o) trabalhador $\rightarrow$ (atua sobre o) objeto. Compreender essa inversão é fundamental para focalizar o trabalho alienado nas sociedades capitalistas.

As sucessivas revoluções industriais cristalizaram tal inversão, que se materializou em tecnologias criadas e operacionalizadas sob a ótica da competição e do lucro. Essa inversão - com sua imanente recriação - implicou rupturas importantes com as formas de civilização anteriores e sedimentou as bases de um processo de alienação do trabalho que, no seio das sociedades urbano-industriais capitalistas atuais, tem mais traços de continuidade e aprofundamento do que rupturas em relação a seus primórdios.

Tal inversão se inicia num tipo de organização do trabalho ainda assentada sobre uma base técnica subjetiva ${ }^{2}$ - a manufatura - no nascedouro da Revolução Industrial. Com métodos coercitivos e violentos, psicológica e fisicamente, era garantida a submissão, bem como a adaptação de seres humanos aos desígnios da produção capitalista mediante salários de fome, castigos corporais, multas e prisões, recrutamento em asilos, workhouses, orfanatos, dentre outros (Marx, 1959; Weber, 1967).

Essas coerções e esses constrangimentos, encarnados na rígida disciplina interna do sistema fabril, impuseram ritmos e intensidade do trabalho em nada compatíveis com a plasticidade e os

${ }^{2}$ Base subjetiva do trabalho em que o savoir-faire do trabalhador e sua destreza no manejo dos instrumentos são a base do processo de trabalho, a exemplo do trabalho artesanal e da manufatura. Distingue-se das configurações subordinadas realmente ao capital, ulteriores, em que os trabalhadores são transformados em apêndices das máquinas e equipamentos, devendo adaptar-se à sua materialidade e aos ritmos impostos. Desapareceu o princípio subjetivo da divisão do trabalho, mas não a subjetividade do trabalhador. O processo de produção passou, então, a estar assentado em bases objetivas, tornando-se passível de análise e mensuração, o que viabilizou e favorece o controle sobre o trabalho. Ver Marx (1959), especialmente os capítulos XI a XIII. limites biopsicossociais dos indivíduos. Inaugurouse um novo tempo social, determinado pelo capital, forjando novos habitus (Bourdieu, 1996, 1983):

O habitus preenche uma função que, em outra filosofia, confiamos à consciência transcendental: é um corpo socializado, um corpo estruturado, um corpo que incorporou as estruturas imanentes de um mundo ou de um setor particular desse mundo, de um campo, e que estrutura tanto a percepção desse mundo como a ação nesse mundo (Bourdieu, 1996, p.144, grifos nossos).

Transpondo a noção de habitus bourdieusiano para a dimensão do trabalho - eixo da sociedade salarial ocidental -, podemos acentuar a percepção de mudanças em várias dimensões da vida social. Na esteira dos novos habitus no trabalho (como será desenvolvido adiante), proliferaram os acidentes, as mutilações e doenças relacionadas ao trabalho desde o século XIX e, contemporaneamente, as epidemias de LER/Dort e os transtornos mentais. Não sem razão, emergiram também práticas de enfrentamento - em defesa da vida e da saúde iniciadas pelas organizações operárias e sindicatos de trabalhadores, expandindo-se e diversificandose com novos atores sociais.

Inicialmente confinados aos muros das fábricas, os agravos se expandiram para os espaços extrafabris, pari passu às subsequentes revoluções tecnológico-industriais e aos processos de urbanização, tornando cada vez mais complexas e interdependentes as relações entre trabalho, saúde e meio ambiente. Nesse sentido, buscamos, através de uma breve retrospectiva histórica, delinear as principais configurações das sociedades capitalistas urbano-industriais, em seus aspectos micro e macrossociais relacionados ao mundo do trabalho.

\section{O MUNDO DO TRABALHO EM RETROSPEC- TIVA: rupturas e continuidades}

A Primeira Revolução Industrial constitui um ponto de partida privilegiado para divisar essas questões. Trata-se de um processo 
multidimensional que inaugurou transformações - profundas e radicais - nas formas de viver e trabalhar, assentadas em relações sociais capitalistas dos homens entre si e na (com) a Natureza. Assim, grandes rupturas com as formas civilizatórias anteriores foram operadas, com destaque para três dimensões: i) relações sociais: configurações societais e relações dos homens entre si, estabelecendo novas mediações entre indivíduo e sociedade; ii) bases tecnológicas, com o uso de fontes de energia cada vez mais potentes, mecanização e automatização crescentes do trabalho e da vida extratrabalho; iii) relações entre as atividades humanas na (com) a Natureza (Franco, 2003).

Sob essa perspectiva, podemos divisar três grandes momentos das sociedades capitalistas ocidentais: i) sociedades industriais pré-fordistas; ii) sociedades fordistas fossilistas (Altvater, 1995); iii) sociedades capitalistas fossilistas flexíveis. Vamos revisitar esses momentos históricos, selecionando alguns referenciais societais, tecnológicos e das relações entre humanidade e natureza, para focalizar as rupturas e continuidades que espelham o aprofundamento da alienação ao longo da constituição desse tipo de sociedade.

Tomamos como pano de fundo as sociedades pré-capitalistas, ou seja, aquelas sociedades que, em termos gerais, eram predominantemente rurais, artesanais, tradicionais e conservadoras, nas quais o tempo social e a vida eram fortemente regidos pelos ciclos naturais, com a observância da alternância do dia e da noite, das estações do ano, etc. Grande era o peso das forças da natureza sobre a vida social, assim como sua sujeição às catástrofes naturais. As forças, os limites e os ciclos naturais estavam incluídos nas representações sociais, fazendo parte do imaginário social. O ser humano fazia parte da Natureza e a ela se subordinava. Capaz de culturalizar a vida (criando práticas e leis sociais), era um "ser da espécie" ainda permeável ao reconhecimento e à sujeição às leis naturais, não sem grandes temores. Em suma, o ser social e o ser biológico-natural estavam amalgamados, imersos num mundo de representações sociais mediado, principalmente, pelo poder central das religiões, do qual emanavam os valores sociais, as noções de certo e errado, os padrões de conduta, o temor, etc. (Durkheim, 2008; Weber, 1967).

O mundo do trabalho e da produção era dependente das forças e dos limites naturais. A tecnologia, baseada em fontes de energia limitadas e inconstantes, movia-se mediante a energia humana, animal, eólica, etc., caracterizando-se, portanto, por uma produtividade e uma capacidade de consumo limitadas pelos elementos da natureza. O trabalho, predominantemente artesanal, estava orientado para a sobrevivência e se caracterizava pela unidade entre trabalho de concepção e execução num mesmo indivíduo. No ocidente, prevalecia o trabalho em regime de servidão, muito distinto do trabalho escravo nas colônias, o que já traduzia o ímpeto de transitar para uma sociedade voltada para o mercado e dominada pelo princípio do lucro.

A consolidação das sociedades urbano-industriais capitalistas ocidentais está assentada em vários processos históricos interligados, dentre os quais destacamos, primeiramente, a crescente mercantilização da vida social (o mercado, de secundário, passa a central na arquitetura social). Essa mercantilização se efetivou, por um lado, através da expulsão de gente das terras ("cercamento" das terras e êxodo rural, processo que persiste ainda hoje em vários países, a exemplo do Brasil), alimentando a formação e o amadurecimento do mercado de trabalho "livre" ao longo dos séculos (Hobsbawn, 1986; Canêdo, 1987; Hardman; Leonardi, 1991). Simultaneamente, ocorreu a progressiva apropriação privada dos elementos da natureza. Desde a revolução científica do século XVII, a natureza passa a ser vista como algo a ser dominado e usado, convertido pela lógica capitalista numa "coisa" a ser apropriada "racionalmente", sem limites (Canêdo, 1987; Passet, 1994; Harvey, 2004).

Essa configuração societal operou uma ruptura radical e profunda com as civilizações anteriores. Trata-se do rompimento com fundamen- 
tos milenares da relação entre natureza e sociedade, solidificando, doravante, uma razão instrumental, utilitarista, que cria uma segunda natureza (Kurz, 1997, 1992; Mészaros, 2006) e impõe novos tempos à vida social, ao trabalho e à produção. São tempos do capital, cada vez mais velozes, em profunda contradição com os tempos naturais - seja dos ciclos da Natureza, seja dos biorritmos humanos -, imprimindo novos habitus (conjunto de práticas sociais) que vão sendo incorporados e naturalizados no cotidiano da vida.

Desde então, o mundo das mercadorias traga, progressivamente, recursos naturais, gente e os mais diversos produtos materiais e imateriais. As relações mercantis permeiam a vida social e tecem a inversão das relações sociais, ou melhor, cristalizam um processo de coisificação das relações sociais e de personificação ou reificação das coisas. São expressões próprias da alienação do trabalho e do fetichismo da mercadoria que constituem os pilares de uma sociedade alienada e patogênica.

... para este [Marx], o fetichismo não é prioritariamente um fenômeno de consciência, mas um conjunto de manifestações de objetividade social, ou mais precisamente, de objetivação de petrificação de certas práticas sociais [...]. As mercadorias são relações sociais que tomam a forma de objetos sociais cristalizados no que lhes serve de suporte material. Em outras palavras, um certo tipo de relações sociais, acima da cabeça dos indivíduos, que produzem e reproduzem objetos sociais consistentes, resistem às volições individuais. Forma-se como que uma segunda nature$z a$, um ambiente quase natural povoado de objetos fascinantes (a fantasmagoria da mercadoria em Marx) que é quase impossível recusar. [...] Vivese mais com os objetos sociais do que com os outros. Mais precisamente, vive-se sua relação com os outros por intermédio dos objetos sociais (Vincent, 2005, p.265-266, grifos nossos).

O período compreendido entre a Primeira Revolução Industrial e o início do século XX (até a Primeira Guerra Mundial) corresponde ao momento pré-fordista das sociedades urbano-industriais de capitalismo liberal (Hobsbawn, 1995, 1986; Canêdo, 1987). No plano microssocial da organização do trabalho, prepondera a concep- ção utilitarista e de dominação do capital, materializada em novas formas e condições que se tornam emblemáticas do sistema fabril. São mudanças profundas, que estabelecem as noções de tempo útil e a caça aos tempos "mortos", em detrimento dos tempos fisiológicos dos trabalhadores. A disciplina e os modos operatórios, instrumentos de controle dos ritmos de trabalho, serão progressivamente aperfeiçoados e incorporados à maquinaria e à tecnologia de produção. O controle social do capital sobre o trabalho, antes exercido predominantemente através da violência física, de prisões, de multas e dos míseros salários coercitivos, passa a ser paulatinamente refinado com a adoção de formas cada vez mais "racionais" de divisão do trabalho e de hierarquização de tarefas, poder, controle, comando e concepção (menos empíricas e crescentemente objeto de pesquisa científica).

São radicais as mudanças na materialidade do processo de produção: uma concentração inédita de grande número de trabalhadores - homens, mulheres e crianças - num mesmo espaço físico, com numerosos e diversos agentes agressivos físicos, químicos e mecânicos, configurando ambientes insalubres de trabalho (Canêdo, 1987; Marx, 1959). Os ambientes intrafabris foram, desde então, incrementados por fontes de energia cada vez mais potentes, passando pelo carvão vegetal, carvão mineral, o vapor e a energia elétrica, prosseguindo com o petróleo - que perpassa as três revoluções industriais - e a energia nuclear a partir da Segunda Guerra Mundial (Hobsbawn, 1995; Altvater, 1995; Freitas, 1996; Passet, 2002). As relações de dominação no trabalho são crescentemente incorporadas à materialidade da produção:

As máquinas [tecnologia] não são ferramentas 'neutras', fazem parte da relação social entre capital e trabalho. São ‘órgãos do cérebro humano, criados pela mão humana, a ciência coisificada' [...]. O trabalho intelectual, de que o capital se apropria, transforma-se em um poder do capital sobre os trabalhadores. [...] Ao invés de aumentar a liberdade e a autonomia dos trabalhadores tanto nos processo de trabalho quanto na empresa, o capital instala o que Marx denomina um 
'despotismo mesquinho e mau'. Por fim, o trabalho ocupa cada vez mais tempo na vida do trabalhador, tendendo a transformar a totalidade desta em tempo de trabalho (Spurck, 2005, p.205206, grifos nossos).

Aprofunda-se a dominação nas relações de trabalho - bem como a alienação do trabalho - crescentemente invisibilizada pela subordinação real do trabalho ao capital (Marx, 1959, 2004a), o que abrirá caminho para a intensificação do trabalho - com a incessante caça aos tempos mortos - e a possibilidade de redução das extensas jornadas de trabalho. Assim:

Entre os trabalhadores e suas criações se instala uma relação de exterioridade. Em suas representações e em suas Weltanschauungen ("visões de mundo") eles não são os sujeitos-criadores das coisas. São, ao contrário, as coisas que são os mestres de seu destino. Vivem em uma opacidade densa, no constrangimento, e, muitas vezes, na angústia (Spurck, 2005, p.199, grifos nossos).

O mundo do trabalho pré-fordista é marcado ainda pelas longas e extenuantes jornadas de trabalho com 12, 14, 17 horas (Marx, 1959; Hobsbawn, 1986; Canêdo, 1987), em contradição com os ciclos fisiológicos (que expressam limites naturais dos indivíduos) e pelos salários baixíssimos (mecanismo de coerção social). As relações entre trabalho e saúde se expressam pela alta frequência de acidentes de trabalho, com mutilações, quedas e traumatismos restritos ao espaço intrafabril, além das doenças profissionais ${ }^{3}$ decorrentes principalmente da inalação das nuvens de poeira, algodão, etc., prevalecentes nesses ambientes de trabalho.

Marca esse período a separação entre o domicílio e o local trabalho, levando a uma crescente concentração espacial e ao processo de urbanização. No seio da sociedade do salariado, são gestadas e consolidadas as figuras sociais do empregador e do empregado, embora subsista a terceirização sob a forma de trabalho domiciliar como apêndice da indústria emergente (têxtil,

\footnotetext{
${ }^{3}$ Trata-se das pneumoconioses que "são doenças causadas pela inalação de aerossóis sólidos e reação tecidual do pulmão.“ (Algranti; Capitani; Bagatin, 1995, p.91).
}

principalmente). Trata-se de uma terceirização secundária que se tornará progressivamente residual no fordismo central até a década de 1970. Como será visto adiante, a partir da crise do fordismo, voltará à tona sob novas roupagens, deixando de ser acessória e passando a elemento estrutural do capitalismo flexível.

O plano macrossocial do período préfordista é construído a partir do mercado "livre" de trabalho, com a generalização das relações assalariadas e baixíssimos salários. A polarização entre os extremos de pobreza e riqueza, nessa sociedade, se expressa pela forte exclusão social de grandes massas humanas (ainda que assalariadas) que sobrevivem com parcos recursos em condições urbano-industriais sub-humanas de saneamento, água e moradia (Hobsbawn, 1996; Canêdo, 1987). Não sem razão, predominam, nessa sociedade, os padrões de adoecimento e morte decorrentes da precariedade social e do trabalho, tais como as doenças infecciosas e da desnutrição ("doenças da pobreza"), com um peso crescente de acidentes de trabalho e das doenças profissionais.

Contudo, a sociedade é movida por forças sociais vivas e, desde a segunda metade do século XIX, são intensos os movimentos políticos e de organizações operárias nos países centrais. Tem início um processo de progressivas conquistas sociais para preservar a vida, que serão consolidadas nas leis de proteção ao trabalhador: Lei do trabalho do menor, limites de duração da jornada de trabalho (10 horas e, posteriormente, 8 horas como referencial para as relações contratuais de trabalho ou seis 6 horas para certas categorias profissionais), regulamentação das horas extras, insalubridade, periculosidade e reconhecimento legal das organizações sindicais, dentre outras.

Apesar de variações entre os países, essa foi uma tendência geral a partir do final do século XIX. O Estado, através das leis trabalhistas, passou a assumir formas de regulação social que reconhecem certos limites biopsicossociais dos trabalhadores. Para além do mundo do trabalho, os movimentos sociais impulsionaram o Estado a implementar po- 
líticas públicas de saneamento, educação, saúde, dentre outras, particularmente na Inglaterra (potência hegemônica, berço e exportadora da Primeira Revolução Industrial), conforme Canêdo (1987). Assim, no final do século XIX, teve início a redefinição do papel do Estado no seio das sociedades capitalistas, com uma maior permeabilidade aos diferentes segmentos sociais (movimentos sociais e organizações sindicais de trabalhadores), ensaiando-se os primeiros sinais de uma razão social do trabalho (noção que será desenvolvida adiante) nas sociedades urbano-industriais capitalistas. Tiveram curso, então, importantes transformações no perfil demográfico e nos padrões de adoecimento e morte nessas sociedades, como veremos.

\section{Sociedades capitalistas fossilistas fordistas}

O século XX - entre a Primeira Guerra Mundial e a década de 1970 (Hobsbawn, 1995) - é o período de consolidação das sociedades industriais centrais - fordistas e fossilistas - e da construção política do capitalismo regulado pelo Estado. Nas primeiras décadas, com turbulentas conjunturas até a Segunda Guerra Mundial, a face social é de forte exclusão, miséria, crises econômicas e políticas, engendrando mobilizações sociais - organizações sindicais e organizações políticas de esquerda e anarquista - com desdobramentos diversos. Sucedem-se a Primeira Guerra Mundial entre 1914 e 1918, em solo europeu, ampliando o mercado para a economia emergente dos EUA; a Revolução Russa de 1917; a Crise de 1929 e a depressão de 1929-1933. Tais turbulências culminaram, por um lado, em desfechos nazifascistas na Itália (1923) e na Alemanha (1933), dentre outros, e, por outro, na consolidação do bloco soviético em crescente polaridade com as sociedades capitalistas. Nos EUA, assim como nos demais países europeus, a saída da crise significou a opção política por um capitalismo regulado pelo Estado (nos EUA, o governo Roosevelt, com a política do New Deal, e na Europa, a construção do Estado de Bem Estar
Social-EBES) (Hobsbawn, 1995).

Trata-se de um momento das sociedades capitalistas centrais em que a regulação social do Estado se deu, sobretudo, por estratégicos e diferenciados incentivos fiscais, políticas trabalhistas e previdenciárias, regulação macroeconômica (políticas agrícola, industrial, etc.) e políticas públicas. A rede de proteção social (aposentadoria, seguro-desemprego, etc.) e o aumento dos gastos públicos com geração de emprego favoreceram a aderência dos indivíduos e das organizações sindicais. Consolidou-se nos EUA, entre 1940 e 1972, e na Europa, entre 1950 e 1970, um capitalismo com reforma social e econômica, no seio do qual foi criado um Sistema Monetário Internacional pelo Acordo de Bretton Woods (1944), para, em princípio, controlar os fluxos de capital e evitar as grandes crises (Filgueiras, 1997, 2000; Druck, 1999).

No plano microssocial, da organização do trabalho, o cenário é composto pelo taylorismofordismo. A organização taylorista do trabalho está assentada na: (i) divisão entre o trabalho de concepção, planejamento, direção e controle (realizado pela gerencia "científica") e o trabalho de execução (pela massa de assalariados); (ii) fragmentação do trabalho, simplificação e esvaziamento do conteúdo do trabalho (noção de posto de trabalho e estrutura de cargos e salários); (ii) análise de tempos e movimentos, cronometragem e padronização das formas de trabalhar; (iii) políticas de punição e premiação individual; sistemas de avaliação da produtividade individual; salário por peça; estímulo à competição (formas de controle e sujeição); operário-padrão (mecânica de gestos, controle de atitudes, novos hábitos, trabalhador forte, ativo e docilizado, sem consciência crítica, sem criatividade), identificação do trabalhador com a empresa (empresafamília); cooperação e harmonia imposta.

A base técnica do taylorismo-fordismo, crescentemente racionalizada e mecanizada, culminou nas linhas de montagem fordistas e equipamentos especializados que viabilizaram não só uma grande escala de produção (produção em 
série), mas também ritmos e pressão cada vez mais intensos de trabalho e aceleração dos tempos sociais, incorporados e materializados nos equipamentos. Em contrapartida, estabeleceu-se, mesmo durante a Crise de 29, a norma salarial fordista, ou seja, de aumentos reais de salário e ganhos de produtividade para os trabalhadores (Ferreira et al., 1994).

Assim, o fetichismo da mercadoria pode plenamente desenvolver-se. Os homens criam a mercadoria, o capital, etc. Em suma, criam tudo o que existe socialmente, mas essas criações, que são seus produtos, parecem a eles criações naturais às quais se submetem. O fetichismo não se limita à produção e ao trabalho. Penetra em toda a sociedade (Spurck, 2005, p.208, grifos nossos).

Em termos macrossociais, o fordismo construiu, material e ideologicamente, a sociedade do ter, a sociedade do consumo de massa. $\mathrm{O}$ fordismo criou novos habitus e um jeito de viver marcado pela disciplina no trabalho, pela criação do homem fordizado (Gramsci, 1984), com mentalidade consumista, aprisionado pela noção do tempo útil. A sociedade ficou impregnada pelo imperativo do lucro e pela obsessão da produtividade e consumo. Em três décadas, firmou-se um capitalismo com face social mais includente, com um mercado de trabalho regulamentado, com a contratualização das relações de trabalho (generalização da negociação coletiva) e rede de proteção social (salários crescentes, benefícios diretos e indiretos). No imaginário social (e nas leis), ergueu-se um importante referencial que incorpora noções dos limites biopsicossociais nas relações de trabalho (duração de jornada de trabalho, horas-extras, férias, seguro-saúde acidentário, aposentadoria, etc.). Operou-se a transformação do trabalho em emprego fordista, ou seja, do trabalho com o corolário fordista de proteção social.

Essa regulação - assentada em pactos sociais - permitiu a expansão da massa salarial e o fortalecimento do mercado interno, levando os países centrais quase ao pleno emprego na década de 1960, realizando-se o ciclo virtuoso do fordismo. Nos países europeus, foram fortalecidas as políticas públicas de saúde, educação e habitação, configurando o Estado de Bem Estar Social e conduzindo à elevação generalizada do padrão de vida da população. Esse longo processo social mudou tanto o perfil demográfico nessas sociedades - com o envelhecimento da população quanto os padrões de morbi-mortalidade, pelo declínio das doenças infecciosas e o peso crescente das doenças crônico-degenerativas, tais como as doenças cardiovasculares, as neoplasias, os transtornos mentais, dentre outras (Hobsbawn, 1986; Canêdo, 1987; Barreto et al.,1993).

No Brasil, o processo de industrialização fordista teve como característica diferencial marcante a face social excludente, configurando a via do fordismo periférico, ou seja, com grande defasagem na capacitação tecnológica e um crescimento econômico concentrador e excludente, sem a norma salarial fordista. Com um passado escravista, um regime autoritário e sem a formação de um Estado de Bem Estar Social, o "milagre brasileiro" foi feito sob a égide do estímulo ao investimento, apenas, sob forte repressão política aos movimentos sociais (Ferreira, 1994). Sua configuração como sociedade urbano-industrial é marcada por transformações tanto no perfil demográfico - o envelhecimento da população, a redução das taxas de natalidade e mortalidade (Souza, 1996) - quanto no quadro de morbi-mortalidade que passou a combinar o aumento das doenças crônico-degenerativas e das causadas por fatores externos (homicídios, acidentes de trânsito e suicídios) com as relacionadas ao trabalho, com um patamar ainda elevado de doenças infecciosas, ${ }^{4}$ sobretudo no tocante à morbidade (Possas, 1989; Barreto et al., 1993; Monteiro, 1995; Navarro et al., 2002; Barreto; Carmo, 2007).

${ }^{4}$ Em relação às doenças infecciosas, no Brasil, Barreto e Carmo
(2007) apontam três importantes tendências nas duas ulti-
mas décadas: doenças transmissíveis com tendência
declinante (varíola, poliomielite, sarampo, tétano, raiva hu-
mana, dentre outras); doenças com quadro persistente (he-
patites virais, tuberculose, malária); e doenças transmissíveis
emergentes e reemergentes (AIDS, dengue, cólera, hantavirose,
dentre outras). Vale salientar a complexidade do quadro de
morbi-mortalidade no Brasil contemporâneo e a diferencia-
ção nos indicadores de saúde por regiões, taxas de pobreza,
gênero, grupos étnicos, dentre outros.


Mundialmente, o taylorismo foi difundido de 1910 a 1920, não sem muitas resistências dos trabalhadores, consolidando-se nos diversos países, apesar dos diferentes matizes e regimes políticos (incluindo desde o fascismo italiano ao stakhanovismo soviético). Os problemas de saúde gerados com essa forma de trabalhar foram inúmeros e em alta frequência, incluindo acidentes de trabalho com mutilações, traumatismos e adoecimentos, pela enorme intensificação do trabalho e mecanização. Essa página virada na história conduziu ao início do controle sobre os agentes agressivos mensuráveis (principalmente os físicos, mecânicos e químicos) e à explicitação de nexos entre saúde e trabalho. A organização taylorista-fordista tornou-se a base de novos adoecimentos, dentre os quais crescentes transtornos mentais, tendo início pesquisas com foco na organização do trabalho e na saúde mental numa perspectiva crítica (Dejours, 1987; Seligmann-Silva, 2011). Os intensos movimentos sociais da década de 1960 colocaram-se criticamente em relação ao way of life fordista, à sociedade do ter sem o ser, levantando as questões dos valores humanos, da ética, da liberdade, da alienação e coisificação dos indivíduos, da guerra, da discriminação étnica dentre outras.

Em relação ao trabalho taylorista-fordista, as organizações sindicais se colocaram contra as cadências, os ritmos, a pressão de tempo, a monotonia, a desqualificação e esvaziamento dos conteúdos do trabalho, e os trabalhadores resistiram com absenteísmo, operações-padrão, recusa ao trabalho taylorizado, demissões voluntárias e greves. Essas organizações foram enfraquecidas com a difusão da flexibilização do trabalho a partir dos anos 1980 nos países capitalistas centrais e, nos anos 1990, no Brasil.

Por outro lado, é necessário considerar que a consolidação da sociedade fordista está associada: (i) à concentração e centralização de capital; (ii) à transformação de conhecimentos científicos em força produtiva (aplicação contínua de conhecimento, gerando tecnologia); (iii) ao uso de fontes de energia predominantemente fósseis, a partir de recursos naturais finitos e não- renováveis, a exemplo do petróleo; (iv) à extração, em grande escala, de recursos naturais e geração de resíduos tóxicos; (v) a uma inédita capacidade de produção e destruição em série; (vi) ao uso - e à criação - de inúmeras substâncias neurotóxicas, cancerígenas, teratogênicas e mutagênicas; (vii) ao surgimento de novos problemas de saúde que vão se manifestar a partir da década de 1970, seja por contaminações lentas e crônicas, seja através de acidentes industriais de grande porte, ambos alcançando os espaços extra-fabris. ${ }^{5}$

As bases energéticas fossilistas do fordismo - com o amadurecimento, principalmente, das indústrias química e de petróleo, além da posterior indústria nuclear - vão romper os limites dos muros das indústrias. Trata-se de riscos industriais (efluentes líquidos, sólidos e gasosos) que migram e modificam os espaços fabris e extrafabris, suporte de um padrão de produção e consumo que agride cronicamente os mecanismos reguladores da Natureza e dos indivíduos.

\section{Sociedades capitalistas fossilistas flexíveis: fa- ces atuais}

Em meados da década de 1970, na esteira da crise econômica - com aumento da capacidade produtiva desproporcional aos mercados, deslocamento do capital produtivo para a esfera das finanças e ciranda especulativa - manifestam-se problemas sociais (distributivos e de redução do emprego) e problemas ambientais.

Assim, a crise do fordismo nos anos 19701980 evidencia tanto problemas econômicos stricto sensu (superprodução, choques petróleo, taxas de juros) quanto questões humanas e societais profundas, que remetem aos pilares dessa forma de civilização. Num processo cumulativo, crise social e ambiental se delineiam, constituindo as duas faces de uma mesma moeda.

No cenário político do neoliberalismo e da

Para maiores detalhes ver Capra (1982); Thébaud-Mony
(1990, 2007); Altvater (1995); Freitas (1996); Franco (1997);
Freitas, Porto e Machado (2000); Jobin (2006); Rigotto (2008). 
mundialização, ${ }^{6}$ as supostas saídas adotadas para a crise foram a liberalização do capital, a flexibilização do trabalho e a desregulamentação social. Elas significaram o recuo das políticas keynesianas do capitalismo administrado pelo Estado e uma redefinição do próprio papel do Estado como agente de regulação social. Na verdade, as "saídas" adotadas e a complacência do Estado aprofundaram as duas faces da crise: a crise social, com o aumento da precarização pela flexibilização do trabalho e a regressão da regulação social e fiscalização do Estado; e a crise ambiental, pela continuidade da depredação maciça do planeta, desproporcional ao engatinhar das políticas ambientais que, além de fragmentadas, não atingem o cerne do problema, qual seja, os próprios padrões capitalistas de produção e consumo em contradição com os sistemas e tempos de autorregulação da Natureza e dos seres humanos.

Vale destacar que a Terceira Revolução Industrial microeletrônica - em resposta à rigidez técnica do fordismo - trouxe novas bases para reconfigurar o mundo do trabalho: a flexibilização sob rígido controle do capital. Essa férrea flexibilização tem viabilizado acelerações e compressões inéditas, aparentemente irrefreáveis, dos tempos sociais. A velocidade dos tempos sociais está na contracorrente dos tempos naturais, inclusive dos tempos fisiológicos humanos (biopsicossociais), fenômeno flagrante e ocultado socialmente. Desde então, tem se aprofundado a loucura social de tentar vencer o tempo com a velocidade, alimentandose um círculo vicioso e patogênico.

Como o trabalho é agora submetido ao capital e neste é integrado o tempo de trabalho e a jornada de trabalho tornam-se plásticos. Ademais, os trabalhadores se tornam, também eles, plásticos, no sentido de que se adaptam às exigências da acumulação do capital criada por eles e que os domina. Estamos, pois, em presença de um dos fetichismos do capital, visto que os trabalhadores criaram essas coisas que os dominam. [...] Em compensação, para o capital, trata-se de uma 'questão de vida ou morte', a saber, impor a mais

\footnotetext{
${ }^{6}$ Ver Chesnais (1996), Bourdieu (1998, 2001), Harvey (2004); sobre a noção de globalização flexível, ver Soane e Taddei (2010).
}

total disponibilidade do trabalhador para satisfazer as exigências, sempre mutáveis, do trabalho (Spurck, 2005, p.199, 204, grifos nossos).

Em contraposição às políticas keynesianas da Era de Ouro, a tônica das políticas neoliberais, desde os anos 1980, repousou na compreensão de que a regulação pelo Estado seria um entrave, ao limitar os interesses e ganhos do capital através da regulamentação do mercado de trabalho (relações contratualizadas e direitos trabalhistas), da política tributária, alfandegária, da concorrência (de empresas estatais) ou da política de subsídios para setores estratégicos e políticas sociais. Portanto, o cerne do ajuste neoliberal para "sair" da crise envolveu: (i) liberar o capital das amarras pela via da desregulamentação; (ii) reconfigurar o mundo do trabalho ou da produção pela flexibilização dos salários e desestabilização dos empregos; (iii) anular as regras de aumento salarial com base na inflação; (iv) anular a cobertura e a extensão da seguridade social (benefícios); (v) liberar os procedimentos de demissão; (vi) destruir o "emprego fordista", ou seja, o trabalho com o corolário de proteção social; vii) recriar o trabalho precário via terceirização ou sub-contratação, além de outras formas de vínculo frágil.

O capitalismo em geral e a produção capitalista em particular são criadores de instabilidade e de incerteza concernentes ao futuro, e finalmente, criam angústias existenciais (Spurck, 2005, p.202, grifos nossos).

No início dos anos 1990, os países periféricos - com um tecido social já fortemente marcado pela precariedade pré-existente - trilharam os mesmos caminhos acima descritos, enfeixados nos planos de estabilização da periferia, de entrada maciça de capital especulativo (capital volátil e veloz) e reformas do Estado com a privatização de bens públicos e empresas público-estatais, com reformas estruturais e de gestão, e com a quebra dos monopólios estatais estratégicos.

Sob a perspectiva do mundo do trabalho, esse processo tem conduzido à desconfiguração das relações entre capital e trabalho, descaracterizando 
as figuras do empregador e do empregado. Simultaneamente, forja-se uma gama de denominações que mesclam os sujeitos sociais - colaboradores, partners, team, parceiros, associados, cooperados - que vão confundir atores sociais tanto na construção das representações e organizações coletivas de solidariedade e resistência, quanto na aplicação das leis trabalhistas. Abre-se o caminho para apagar da memória social os referenciais de relações contratuais de trabalho conquistados cumulativamente desde meados do século XIX e consolidados na legislação trabalhista durante o fordismo. São referenciais fundamentais, na medida em que incorporam, ainda que timidamente e no seio de uma sociedade regida pela razão instrumental, o reconhecimento de limites biopsicossociais dos seres humanos, simbolizando o germe de uma razão social do trabalho.

A precarização, caracterizada por muitos autores como um processo multidimensional de fragilização das formas de inserção e dos vínculos sociais, vira uma tônica no mundo laboral que caminha pari passu com a intensificação do trabalho. Ela ocorre por mecanismos tais como o irrefreado aumento da velocidade e do ritmo do trabalho; a multifuncionalidade (com acúmulo e desvio de funções, o que implode as noções de posto de trabalho, de cargos e salários), dentre outros elementos do toyotismo (modelo japonês) favorecidos pelo patamar tecnológico da Terceira Revolução Industrial microeletrônica.

Os avanços tecnológicos não têm sido utilizados para reduzir a jornada de trabalho e gerar emprego, particularmente desde a Terceira Revolução Industrial. Na prática, tem ocorrido a extensão das jornadas de trabalho, com o apagamento da noção de horas-extras e o recurso indiscriminado ao trabalho em turnos e noturno. Tem se criado o habitus de viver, consumir e trabalhar ininterruptamente, em não importa que horários, apagando da memória social os fundamentos constitutivos da espécie humana, estruturantes dos ciclos fisiológicos inscritos na memória biológica de cada indivíduo (alternância das polaridades de atividade e repouso, de noite e dia, de contração e relaxamento, etc.).

Sob a gestão pelo medo - com ameaça de demissão, de desmoralização profissional, de descartabilidade social - combinada com o discurso participativo, impõe-se a prática da participação forçada e controlada, que leva à autoaceleração e à submissão dos indivíduos às metas e à intensificação do trabalho. Prevalece o discurso participativo ao lado das práticas de "apagamento dos vestígios" e construção da mentira dentro das empresas, instituições e corporações (Dejours, 1999).

No Brasil, generalizou-se a flexibilização do trabalho via terceirização. ${ }^{7}$ A maioria das análises e estudos empíricos, particularmente da Sociologia do trabalho, tem demonstrado que a terceirização foi adotada como política de gestão flexível do trabalho, dentre outras, o que tem levado à precarização social. Trata-se de um processo multidimensional que atinge o trabalhador-como indivíduo, família, coletivo de trabalho e cidadão -, esgarçando o tecido social ao fragilizar ou degradar: (i) os vínculos de trabalho e relações contratuais; (ii) a organização e condições de trabalho; (iii) a saúde e segurança no trabalho; (iv) o reconhecimento e valorização simbólica na construção de identidade individual e coletiva; (v) a representação e organização coletiva, fragilizando os trabalhadores como atores sociais. ${ }^{8}$

\section{TRABALHO ALIENADO: quatro aspectos da abstração dos limites humanos e da natureza}

As transformações das sociedades urbanoindustriais, resumidas na periodização apresentada, contêm mudanças ininterruptas da base técnica subjetiva do processo de trabalho para uma base objetiva crescente, através da mecanização e informatização, buscando racionalizar o controle do trabalho, impor os ritmos e tempos do capital

7 Trata-se da transferência da atividade de um "primeiro" que deveria se responsabilizar pelos encargos e direitos trabalhistas que pautam as relaçóes entre empregado e empregador - para um “terceiro”. Ver Carelli (2003); Druck e Franco (2007).

${ }^{8}$ Para maiores detalhes ver Druck e Franco (2007); Franco, Druck e Seligmann-Silva (2010). 
no processo de produção (bem como na circulação e no consumo). A vontade de neutralizar quaisquer práticas de resistência dos assalariados e a tentativa de consagrar a empresa como o espaço eficiente - harmônico, sem conflitos, perfeito, exato, calculável, previsível, programado, programável, eficiente e, mais recentemente, de excelência - impulsionou continuamente essa materialização da base objetiva do processo de trabalho e - contemporaneamente - a quebra dos direitos do trabalho e dos possíveis referenciais de uma razão social do trabalho, via flexibilização e precarização do trabalho.

Tecnologias (e no limite, a ciência) têm sido instrumentalizadas como meio de aumentar a produtividade, de garantir a competitividade e como meio de sujeição dos homens e da natureza. Ambos - homens e natureza - passaram a ser representados como meros recursos instrumentais sob variadas denominações ("fator humano, recursos humanos, recursos naturais, insumos, matérias-primas"...), cujos biorritmos e ciclos naturais são negligenciados no equacionamento do mundo da produção e do trabalho com o do livre mercado. Essa inversão do sentido do trabalho e a busca obsessiva pela produtividade induziram uma tendência à redução da ciência aos limites de sua aplicação como tecnologia produtiva do capital e de dominação, ameaçando, contemporaneamente, a própria autonomia da produção científica.

Em meio às mudanças na configuração do mundo do trabalho, persiste um eixo ou fio condutor de análise: o trabalho alienado - que se aprofunda - e suas consequências em termos de saúde e destruição do meio ambiente. Tais processos, com matizes culturais e políticos variados, envolveram diferenciados mecanismos de coerção na organização do trabalho, ao longo do tempo, e múltiplas expressões de resistência, assim como de transição e adaptação aos novos habitus no trabalho criados pela inversão para o arranjo instrumento de trabalho e tecnologia $\rightarrow$ trabalhador $\rightarrow$ objeto.

A materialização da inversão desse arran- jo é apreendida pelo conceito de subsunção real do trabalho ao capital em Marx (1959, 2004a). Na verdade, o conceito de alienação do trabalho de Marx sintetiza um longo processo histórico e tem longo alcance, permitindo focalizar as possíveis consequências dessa inversão e a perda do sentido social do trabalho para o indivíduo.

Que sentido tem esse modo de trabalho, com referência ao desenvolvimento do homem? Com esta pergunta a teoria marxista abandona o "nível da economia política”. [...] Longe de ser uma mera atividade econômica (Erwerbstatigkeit), o trabalho é a "atividade existencial" do homem, sua 'atividade livre, consciente' - não um meio de conservação da sua vida (Lebensmittel), mas um meio de desenvolvimento da sua "natureza universal”. As novas categorias vão avaliar a realidade econômica sob o ponto de vista da ação desta sobre o homem; suas faculdades, poderes e necessidades. Marx resume estas qualidades humanas quando fala da 'essência universal' do homem [...]. Estes termos remontam a Feuerbach e a Hegel. A verdadeira natureza do homem está na sua universalidade. [...] O homem só é livre se todos os homens forem livres e existirem, como "seres universais". Quando for atingida essa condição, a vida será moldada pelas potencialidades do gênero Homem, que abarca as potencialidades [e diversidade] de todos os indivíduos que contém. A preeminência dada a esta universalidade incorpora a natureza ao autodesenvolvimento da humanidade. O homem é livre se "a natureza é trabalho seu e sua realidade", de modo que ele "a si mesmo se reconhece num mundo que ele mesmo construiu” (Marcuse, 2004, p.238-239).

Compreender o trabalho alienado permite-nos entrever três grandes rupturas fundamentais para a vida e a saúde, operadas desde o século XVIII, como vimos: a ruptura nas relações dos homens com a natureza, a ruptura dos laços dos homens entre si e, também, do homem consigo mesmo.

Com a valorização do mundo das coisas aumenta em proporção direta a desvalorização do mundo dos homens. O trabalho não produz só mercadorias; produz a si mesmo e ao trabalhador como uma mercadoria, e isto na proporção em que produz mercadorias em geral. Marx (1983, p.148150).

A partir dessa construção conceitual, passamos a resgatar quatro aspectos ou faces do trabalho 
alienado, ${ }^{9}$ como perspectivas para transpor e refletir sobre a realidade atual.

\section{Primeiro aspecto: o trabalho sem arte}

Como vimos, o produto do trabalho humano foi reduzido à mera condição de "coisa" portadora de valor, adquirindo a duplicidade de valor de uso e valor de troca. O ser humano trabalhador, criador e produtor - também foi reduzido à coisa-mercadoria específica, que tem a capacidade de criar mais valor (para o capital) do que encerra em si mesmo. Ao longo dos últimos séculos, a ótica empresarial e as teorias da organização confundiram o valor existencial e ético do ser humano com a noção de valor para o capital, buscando reduzi-lo e confiná-lo ao "universo redentor" da organização.

A ideologia contemporânea, que enaltece, de modo mistificador, a "valorização do ser humano na empresa" e a "excelência" - as quais têm produzido, segundo Seligmann-Silva, o apagamento ético, a insensibilidade, a ruptura da sociabilidade e a desestabilização da saúde (SeligmannSilva, 1994, 1995, 2001, 2011) - é prisioneira dessa lógica redutora e originária do século XVIII. Contemporaneamente, a rigor, não houve ruptura quanto a esse aspecto. A flexibilização do trabalho trouxe, sim, mudanças na aparência dos fenômenos, o refinamento dos discursos e a ampliação dos instrumentos de controle sobre o trabalho dominado e do sequestro da subjetividade dos indivíduos. Essencialmente, aprofundou-

${ }^{9}$ É necessário referir a diversidade de ênfases e interpretações dos vários autores sobre as principais características ou aspectos do conceito de alienação de Marx. Ainda que essa discussão teórica não caiba no escopo deste ensaio, vale esclarecer que, ao invés de destacarmos ou acentuarmos as discrepâncias, entendemos tais diferenças como reveladoras da complexidade do conceito, dos olhares circunstanciados dos diferentes autores - que abrangem um vasto período histórico com vistas à atualidade, ou não, do conceito em face das mudanças sociais - e da forma esparsa e inacabada pela qual se encontra na própria obra de Marx; e, por fim, pela delicada rede de mediaçóes e complexa interligação entre os sentidos e interpretações que tais características ou dimensões do conceito de alienação comportam. Ver Marcuse (2004); Mészaros (2006) Giddens (1990); Bottomore (2001), Spurck (2005); Antunes (2002) e Marx (1983, 2004b). se o processo de alienação que mergulhou na subjetividade humana, intencional e racionalmente, radicalizando-se a dominação, com sérias consequências para a sociabilidade e a saúde, especialmente a saúde mental (2011).

Emergiu, assim, uma espécie de coerção à perfeição humana, algo que se transformou em invectiva onipotente e onipresente nas empresas. Esta invectiva se evidencia como profundamente perversa, na medida em que ignora os limites e a variabilidade dos processos fisiológicos e mentais dos seres humanos, como a análise dos princípios e paradoxos da excelência permite constatar (Franco; Druck; Seligmann-Silva, 2010, p.23).

Ao lado da "valorização do ser humano", num aparente paradoxo, opera-se a banalização da injustiça social com a descartabilidade das pessoas no mundo do trabalho, a instrumentalização do medo na gestão das empresas e a violência psicológica.

A injustiça e o sofrimento no trabalho dominado nada têm de novo. A novidade que assusta é a de que esteja se disseminando rapidamente a banalização do mal, isto é, a tolerância em relação à injustiça e ao sofrimento. Dejours apontou [...] para a íntima associação que existe entre processos de natureza política e processos de ordem psicológica. [...] "insensibilidade ética" [...] estaria generalizando-se em certos escalões gerenciais que recebem "missões" para atingir "metas de enxugamento', abstraindo a dimensão humana do que isto significa. Esta insensibilidade explicaria a indiferença e a naturalidade com que a própria escalada do desemprego passou a ser interpretada em vários ambientes. (Seligmann-Silva, 2011, p.26)

\section{Segundo aspecto: o trabalho dominado}

A dominação está inscrita na relação do trabalhador com o ato da produção, está inscrita e materializada no processo de trabalho. Esse segundo aspecto nos remete ao crescente controle sobre o trabalho, com a imposição do modo de trabalhar e o estabelecimento dos modos operatórios e scripts nos cenários de trabalho, tanto na produção de mercadorias materiais, quanto imateriais (Spurck, 2005). 
... a alienação não se mostra apenas no resultado, mas no ato da produção, dentro da atividade produtiva mesma. Como o trabalhador poderia se defrontar alheio ao produto da sua atividade se no ato mesmo da produção ele não se alienasse de si mesmo ? Pois o produto é só resumo da atividade, da produção. Se por conseguinte o produto do trabalho é a exteriorização, então a produção mesma tem que ser a exteriorização ativa, a exteriorização da atividade da exteriorização. [...] Em que consiste a exteriorização do trabalho ? Primeiro: que o trabalho é exterior ao trabalhador [...] não pertence à sua essência... que, portanto, ele não se afirma, mas se nega em seu trabalho [...] mas mortifica a sua physis e arruína a sua mente. [...] O seu trabalho não é portanto voluntário, mas compulsório, trabalho forçado. Por conseguinte, não é a satisfação de uma necessidade [necessidade lógica e (ou) ontológica], mas somente um meio para satisfazer necessidades fora dele. A sua alienidade emerge com pureza no fato de que, tão logo não exista coerção física ou outra qualquer, se foge do trabalho como de uma peste. $[\ldots]$ // trabalho // não é seu próprio [...] nele não se pertence a si mesmo, mas a um outro [...] Pertence a um outro, é a perda de si mesmo. (Marx, 1983, p.152-153, grifos nossos).

O trabalho prescrito tem sido revestido por uma roupagem "científica" desde o final do século XIX. A imposição do modo de trabalhar foi consagrada e radicalizada pelo taylorismo (the one best way), e, sucessivamente, enriquecida e refinada pelas diversas escolas de humanização do trabalho que se consolidaram na esteira das resistências e críticas ao taylorismo no século $\mathrm{XX} .{ }^{10} \mathrm{~A}$ imposição do trabalho prescrito será redefinida, fortemente, pelas mudanças na estratégia de dominação com a difusão das práticas participativas japonesas e a flexibilização do trabalho.

Além do saber operário, que o fordismo expropriou e transferiu para a esfera da gerência científica, para os níveis de elaboração, a nova face do capital, da qual o toyotismo é a melhor expressão,

\footnotetext{
${ }^{10}$ Nos EUA, destacam-se a Escola das Relações Humanas, desenvolvida por Elton Mayo na década de 1930; na década de 1950, a Teoria de Hierarquia de Necessidades de Maslow; a Teoria X e a Teoria Y de Douglas McGregor, a Teoria da maturidade-imaturidade de Argyris e a Teoria Motivação Higiene de Herzberg. As teorias contemporâneas de motivação, segundo Robbins: a Teoria ERC - exisas de motivação, segundo Robbins: a Teoria ERC - exis-
tência, relacionamento e crescimento, de Clayton Aldefer; a Teoria de Necessidade de McClelland (necessidades de realização, poder e afiliação); a Teoria de Avaliação Cognitiva (final dos anos 60); a Teoria de Determinacão de Metas (final dos anos 60); a Teoria do reforço (behaviorista); a Teoria da Equidade de Pearson; a Teoria da Expectativa de Victor Vroom. Para maiores detalhes, ver Robbins (1999).
}

retransfere o savoir faire para o trabalho, mas o faz visando apropriar-se crescentemente da sua dimensão intelectual, das suas capacidades cognitivas, procurando envolver mais forte e intensamente a subjetividade operária (Antunes, 2002, p.40).

A difusão da flexibilidade é simultânea à rigidez do mercado absoluto e à precarização das condições de vida e de trabalho, que viabilizam a coexistência paradoxal de práticas participativas, ditas consensuais, com a rigidez da competitividade, a inflexibilidade do lucro e da dominação no final dos séculos XX e XXI.

Desde Taylor, passando pelas escolas de humanização do trabalho até a flexibilização do trabalho com o toyotismo, há uma sucessão de tentativas para higienizar socialmente o processo de trabalho (expurgando conflitos, diferenças de interesses e negando a existência de classes sociais) muito nos moldes durkheimianos de uma concepção da divisão social do trabalho harmônica e tendendo ao equilíbrio. Suas contradições e aspectos aviltantes para a condição humana são vistos como exteriores à organização do trabalho capitalista (que, na pós-modernidade, não seria mais capitalista!), superáveis, portanto, na medida em que a divisão do trabalho avance, engendrando a solidariedade orgânica. É a tentativa de reintroduzir o sentido do trabalho a partir de seu aspecto técnico e a-histórico, reduzindo o valor ético dos seres humanos à dimensão do valor do capital, esvaziando-os ontologicamente e identificando-os com a empresa. É a reestruturação epidérmica, de superfície, que não toca nem os fundamentos nem a prática das organizações, que continuam a afirmar, praticar e exigir o lucro e a competição como valores máximos.

Os indivíduos são parte da organização e, cumprindo o seu papel nesse "todo", nesse sistema social - inquestionável -, deveriam, ceteris paribus, nessa rede de relações, na versão

Vale referir ainda a Teoria Z de William Ouchi, e a importante Escola Sócio-Técnica, desenvolvida no Instituto de Tavistock, Inglaterra, por desmistificar o determinismo tecnológico, reconhecer a importância da participação sindical e preconizar mudanças de caráter coletivo na organização do trabalho, dentre outros aspectos. Para maiores detalhes ver Lemos (2001). 
parsoniana, mais atualizada, realizar-se e desenvolver-se como indivíduos plenos, identificados com a organização. O sistema social, a organização é perfeita, ou, se ainda não o é, deve ser continuamente aperfeiçoada. Na visão restrita da mecânica do relógio, atualizada no mundo do trabalho pela visão mecanicista de Taylor (da organização como máquina), ou na visão dos organismos complexos (sistemas sociotécnicos, enfoque dos sistemas abertos, da teoria da contingência, da ecologia organizacional), ou na metáfora das organizações como cérebro, numa analogia aos sistemas holográficos, ${ }^{11}$ os sistemas sociais não são historicizados nem contextualizados.

Assim, persiste a abstração dos limites dos indivíduos e da natureza - inerente à lógica do mercado, do lucro e da dominação pelo capital, imposta aos sistemas informacionais e de feedbacks. No marco da globalização e do neoliberalismo, a exacerbação da competitividade, a busca pela excelência e a gestão pelo medo têm sido o acicate da precarização do trabalho contemporâneo. Em consequência, os reais desafios permanecem intocados, travestidos em epifenômenos e mudanças epidérmicas, pontuais, reiteradoras do fetichismo, a exemplo do fascínio generalizado pelas inovações tecnológicas, a maquiagem das práticas participativas, as democracias representativas vazias, a mise-enscène do consenso, a mentira transfigurada em verdade e a insensibilidade ética (Dejours, 1999; Seligmann-Silva, 2011).

A violência da excelência em geral é marcada pela sutileza e imposta de modo a disfarçar a domi-

11 "Muito recentemente, o cérebro tem sido comparado com um sistema holográfico, uma das maravilhas da ciência do laser. A holografia, inventada em 1948 por Dennis Gabor, usa uma câmera sem lentes para registrar informação de maneira a armazenar o todo em todas as partes. Raios de luz entrecruzados criam um 'modelo de interferência' que dispersa a informação que está sendo gravada num disco fotográfico, conhecido como holograma, que pode, então ser iluminado para recriar a informação original. (...) A holografia demonstra, de forma muito concreta, que é possível criar processos nos quais o todo pode ser contido em todas as partes, de tal forma que cada uma e todas as partes representem o todo. O neurocientista Karl Pribram da Universidade de Stanford sugeriu que o cérebro funcione de acordo com os princípios holográficos: que a memória é distribuída através do cérebro e pode assim ser reconstituída a partir de qualquer das partes.” (Morgan, 1996, p.84). nação, por exemplo, sob discursos e projeção de cenários de um futuro promissor para a empresa e para seus colaboradores (expressão que oculta a relação de poder embutida na subordinação capital/trabalho). A imposição dos paradigmas da excelência acontece juntamente com a imposição do medo de discordar, já que o dilema é aderir ou ser excluído. Isso dá lugar a uma verdadeira coação ao fingimento - pois todos precisam mostrar-se excelentes, energizados para cumprir as metas e, por conseguinte, fingir (até para si mesmos) que estas são sempre alcançáveis (Franco; Druck; Seligmann-Silva, 2010, p.238).

\section{Terceiro aspecto: a perda da razão social do trabalho}

Concerne às relações dos homens entre si - na esteira das relações de apropriação ou dominação e perda da razão social do trabalho (Druck; Franco, 2007) - e do homem consigo mesmo (perda de si mesmo), indissociáveis, a rigor, dos demais aspectos.

Uma consequência imediata do fato de o homem estar alienado do produto do seu trabalho, da sua atividade vital, do seu ser genérico, é o homem estar alienado do homem. [...] Em geral, a proposição de que o homem está alienado do seu ser genérico significa que um homem está alienado do outro, tal como cada um deles da essência. // ...// humana. [...] Na relação do trabalho alienado, portanto, cada homem considera o outro segundo o critério e a relação na qual ele mesmo se encontra como trabalhador. [...] Se o produto do trabalho me é alheio, [...] se a minha própria atividade não me pertence, sendo uma atividade alheia obtida por coação, a quem pertence então? (Marx, 1983, p.158-159, grifos nossos).

Convém destacar que, em relação à essência da natureza humana, Marx:

... nega que o homem seja um ser essencialmente egoísta, porque não aceita algo como uma natureza humana fixa (e, na realidade, não aceita nada fixo). Na visão de Marx, o homem não é, por natureza, nem egoísta nem altruísta. Ele se torna, por sua própria atividade, aquilo que é num determinado momento. E assim, se essa atividade for transformada, a natureza humana hoje egoísta se modificará, de maneira correspondente. Nesta concepção, a essência humana está na sociabilidade (o conjunto de relações sociais) e não o egoísmo. Uma natureza dotada de plasticidade - não fixa, transformável - cujo desenvolvimento ("rea- 
lização adequada” "não pode ser a concorrência - essa 'condição inconsciente da humanidade' que corresponde ao egoísmo e ao bellum omnium contra omnes hobbesiano -, mas a associação consciente (Mészaros, 2006, p.137-138).

Um sistema social baseado na competição, no mercado e na apropriação ilimitada de bens comuns sociais e de bens comuns da natureza (Seoani; Taddei, 2010) conduz à perda da razão social da vida, significando a abstração do "lado social da vida humana" (Mészaros, 2006, p.160) e a alienação do homem de seu ser genérico, do homem pelo homem, alienação de sua própria essência (sociabilidade). Trata-se de uma 'segunda natureza' do homem, no âmbito de uma sociedade alienada, embotada quanto às potencialidades da natureza humana.

Em todos os casos, a alienação surge como um divórcio entre o individual e o social, entre o natural e o autoconsciente. Segue-se, em contraposição, que numa relação humana não-alienada, o individual e o social, o natural e o autoconsciente devem estar juntos - e formar uma unidade complexa. [...] O enriquecimento do sujeito físico, sozinho, é o enriquecimento da "mercadoria humana", que é um "ser desumanizado tanto espiritual quanto corporalmente" (32). A luta contra a alienação é, portanto, aos olhos de Marx, uma luta para resgatar o homem de um estado no qual "a expansão dos produtos e das carências o torna escravo inventivo e continuamente calculista de desejos não humanos, requintados, não naturais e pretensiosos" (Mészaros, 2006, p.160163, grifos nossos).

\section{Quarto aspecto: ser humano desenraizado}

Refere-se à Natureza que nos envolve, nos entranha, nos contém e nos supera. Na sociedade urbano-industrial contemporânea, especificamente, ocorre a desvalorização do mundo humano e a valorização do mundo das coisas (a coisificação da rede de relações sociais). Vive-se num espaço-tempo construído e recriado socialmente, sob a égide dessa ilusão.

... diz respeito, grosseiramente, à ordem de produção totalmente artificial à qual o trabalhador estava submetido. Ordem 'artificial' por que não respeita as leis da biologia, por exemplo (fadiga, ciclos de vigília e de sono, morfologia, estações climáticas, ritmo pessoal etc.), e sim 'leis' ditadas pelas exigências não-naturais de uma produção maximizada. Notemos que se encontra, já aí, uma preocupação com a ordem ambiental, que não será considerada, infelizmente, pela evolução ulterior das 'ciências' econômicas. (Calvez, 1978 apud Aktouf, 1996, p.106)

A coisificação da existência produz homens desligados dos laços que os unem entre si - através dos laços sociais, realizando a sociabilidade inerente que lhes confere sua humanidade - e o ser humano desligado do "ser da espécie" que os une umbilicalmente à natureza.

Argumentamos que os homens e a natureza são e não são separáveis um do outro. Pontuamos que é necessário olhar com prudência (e lente histórica) a formulação de Marx sobre o trabalho alienado no que concerne à relação homem-natureza, que ora revela uma visão antropocêntrica, ora não. Assim, no nosso entender, é importante reconhecer o alcance, atualidade e profundidade dessa teoria, buscando sintonizá-la naquilo que seria difícil perceber no século XIX, mas que os séculos XX e XXI evidenciam: os indivíduos humanos - a espécie humana - estão imersos na natureza, dependem dela para viver, são parte dos fios de sua rede e, simultaneamente, têm o poder (histórico e tecnológico) de tocá-la como nenhuma outra espécie viva, até então conhecida, e de transformála numa segunda natureza e até de destruir parte dela, que é este planeta. Assim, sem dúvida, o homem é o sujeito-agente da história, e, nesse processo, modifica a natureza incessantemente, modificando a si próprio. "No entanto, antes do aparecimento da humanidade, os seres já eram seres" (Damásio, 1996, p.279). Antes da humanidade, a natureza já existia sem os homens.

Consequentemente, precisamos reconhecer que a natureza não é redutível à espécie humana e que não deve ser recriada à nossa medida. Precisamos admitir que somos, sim, os agentes da história, das diferentes civilizações, criadores dos tempos sociais, mas não somos deuses. 
Que essas afirmações não sejam entendidas como apelos de volta a uma natureza intocada (algo impossível), ou de lamentação quanto ao processo histórico de desencantamento do mundo (Weber, 1967; Bourdieu, 1979). Não. Pensamos ser necessário o re-encantamento do mundo, pelo reconhecimento da complexa teia da vida, sua plasticidade e limites. Ou seja, por uma comunhão entre razão livre da dominação ou alienação, redimensionada e colocada pelo bom-senso em seu devido lugar - e sentimento, umbilicalmente ligado à ética e aos valores da dignidade e respeito humano, àquilo de mais fino, sublime e delicado que confere grandeza ao espírito humano e que nos permite conviver. A persistência do império de uma racionalidade inflada e instrumentalizada pelos interesses e poder de elites vorazes mantêm-nos a chafurdar na pequenez humana da competição, da opressão, do darwinismo social, banalizados e afirmados como inatos e inexoráveis. A grandeza e a pequenez humana são, ambas, possíveis; sabemos disso no dia a dia. A natureza humana tem plasticidade, e sua transformação emancipatória e desalienante é uma necessidade histórica, pelo processo ou fluxo incessante de interiorização e exteriorização mediado pelos habitus. Nesse sentido, precisamos recriar, re-fundar uma razão social e os tempos sociais, de modo a compatibilizá-los com os ciclos naturais que existem no macro e microcosmo (sociedade e natureza, indivíduo e sociedade).

Para a compreensão da importância de focalizarmos o tempo social, são decisivas as contribuições de Bourdieu. O autor, muito claramente, coloca que

... a ordem social é, antes de mais nada, um ritmo, um tempo. Conformar-se com a ordem social é primordialmente respeitar os ritmos, acompanhar a medida, não andar fora de tempo. [...] Adotar ritmos desusados e itinerários próprios significa já excluir-se do grupo (Bourdieu, 1979, p.47-48, grifos nossos).

Ora, nas sociedades urbano-industriais contemporâneas, a inclusão na ordem social pressupõe a imersão dos indivíduos em tempos sociais ao avesso de seus biorritmos. Nessa linha de argumentação, é importante retomar o conceito de habitus de Bourdieu:

... [habitus é um] modo de engendramento das práticas, condição de construção de uma ciência experimental da dialética da interioridade e da exterioridade, isto é, da interiorização da exterioridade e da exteriorização da interioridade. As estruturas constitutivas de um tipo particular de meio (as condições materiais de existência características de uma condição de classe), que podem ser apreendidas empiricamente sob a forma de regularidades associadas a um meio socialmente estruturado, produzem habitus, sistemas de disposições duráveis, estruturas estruturadas predispostas a funcionar como estruturas estruturantes, isto é, como princípio gerador e estruturador das práticas e das representações que podem ser objetivamente "reguladas" e "regulares" sem ser o produto da obediência a regras, objetivamente adaptadas a seu fim sem supor a intenção consciente dos fins e o domínio expresso das operações necessárias para atingilos e coletivamente orquestradas, sem ser o produto da ação organizadora de um regente. [...] as práticas que o habitus produz (enquanto princípio gerador de estratégias que permitem fazer face a situações imprevistas e sem cessar renovadas) são determinadas pela antecipação implícita de suas consequências, isto é, pelas condições passadas da produção de seu princípio de produção de modo que elas tendem a reproduzir as estruturas objetivas das quais elas são, em última análise, o produto.[...] O habitus está no princípio de encadeamento das 'ações' (1983, p.60-61, grifos nossos).

Transpondo o conceito de habitus para a dimensão do trabalho, compreendemos o habitus como a construção dinâmica de ajustes, adaptações e resistências pelos coletivos e indivíduos, para viverem, no cotidiano, em sociedades estruturadas e estruturantes. Trata-se de um complexo de múltiplas mediações. Assim, o habitus sintetiza o vórtice de tempos distintos, naturais e históricos: os tempos sociais, o tempo cósmico, os tempos biológicos e psíquicos. Condensa, portanto, os níveis individuais, microssociais e macrossociais em que se plasma o tempo real vivido, presente e imaginado. As relações dos seres humanos com a natureza são confluências, vórtices de tempo cósmico, de um tempo histórico-social, dos tempos biopsicossociais, dos biorritmos... São construções e modulações 
na confluência de todos esses tempos. Os habitus são construtos humanos contínuos, que têm como referência, consciente ou inconscientemente, essa complexa existência, e têm o sentido de viabilizar a vida cotidiana neste turbilhão de tempos entrelaçados, plasmando distintos ritmos, potencialidades e limites. Os tempos sociais são construtos humanos, distintos dos tempos naturais que se nos sobrepõem e que, socialmente, a humanidade insiste em ignorar e negligenciar.

Os danos à saúde relacionados ao trabalho, assim como os danos ao meio ambiente em nossa civilização, têm um tronco originário comum, que revela a incompatibilidade entre estruturas cristalizadas dos padrões de produção e consumo criados e os limites biopsicossociais dos seres humanos e da natureza (ritmos e ciclos físico-químicobiológicos dos ecossistemas). Os habitus, construídos ou em transição, são tentativas de adaptação humana. A natureza, stricto sensu, também tem seus mecanismos adaptativos, mas ambos têm limites (não redutíveis uns aos outros) que transcendem a ordem social ou dela escapam.

A sociedade do trabalho alienado, erigida ao longo da revolução industrial capitalista, desde há quatro séculos, tem produzido incessante e cumulativamente novos riscos ou danos, típicos desta civilização, e potencializado riscos ou danos préexistentes. A historicidade dos riscos e sua origem ${ }^{12}$ revelam a centralidade do trabalho alienado na vida e morte dos indivíduos e na depredação do planeta nas sociedades contemporâneas.

E como a relação do homem com a natureza é mediada por meio de uma forma alienada de atividade produtiva, 'a natureza antropológica' fora do homem traz as marcas dessa alienação de forma cada vez mais acentuada, demonstrada graficamente pela intensidade da poluição que ameaça a própria existência da humanidade (Mészaros, 2006, p.100).

${ }^{12}$ Ainda que não seja objeto do presente ensaio, vale destacar a argumentação crítica de Castel (2009) quanto à concepção de ‘sociedade do risco’ de Ulrich Beck (1998), amplamente disseminada. Castel enfatiza a necessidade de desconstruir a concepção globalizante do risco que prevalece atualmente, preconizando a distinção dos riscos na sociedade contemporânea (que o autor preliminarmente diferencia em três tipos de configurações ou constelações - riscos sociais; populações de risco e riscos concernentes
Novos problemas de saúde no trabalho afloraram e constituem indicadores da discordância entre os novos habitus no trabalho alienado e os limites biopsicossociais dos indivíduos. Bourdieu aponta para a discordância entre as estruturas e os habitus em situações de transição entre uma economia pré-capitalista e uma economia capitalista. Ao focalizarmos o mundo do trabalho, chamamos a atenção para as possíveis discordâncias entre habitus no trabalho, em formação ou já formados, e as estruturas dinâmicas biopsicossociais dos indivíduos.

A história do século XIX evidenciou, sobretudo, os limites da vida humana no trabalho alienado, que originaram o campo da medicina do trabalho, e, posteriormente, o da ergonomia e o campo da saúde mental. A história do século XX revelou os limites da natureza, de seus mecanismos reguladores, originando as ciências do meio ambiente. Essas dimensões e questões são indissociáveis, pois os homens estão umbilicalmente ligados à Terra e ao cosmos. A alienação produz artificialmente uma dupla ruptura nessa ligação. O seu equacionamento encontra-se em interdependência e o reatar destes elos, o religar, não cabe no escopo de uma civilização ou sociedade dedicada à mercadoria e à dominação.

A flexibilização do trabalho mantém esse processo de inversão e o radicaliza. Assim, tanto o despertencimento social quanto o despertencimento em relação à Natureza revelam o atributo inerente do capitalismo de ser um padrão civilizatório incapaz de incorporar os limites humanos e da Natureza.

Trata-se de um padrão civilizatório inerentemente avesso à natureza e à vida humana, na medida em que sua perspectiva é a dominação, o controle e a apropriação. Tocamos, aqui, nas raízes e fundamentos de uma sociedade patogênica cujos tempos sociais são incompatíveis com os biorritmos humanos (tempos para autorregulação

ao meio ambiente) -, ao invés de adicioná-los. Os riscos são heterogêneos (quanto à origem, à estrutura e aos efeitos). Não são cumuláveis, tendo em comum apenas o produzir ameaças e medo. O autor adverte que esse tipo de adição (de medos) - ou de reducionismo, no nosso entender- nunca foi um bom guia, seja para a reflexão, seja para a ação. "O amálgama dos riscos conduz, sobretudo, à confusão intelectual e à impotência prática” (Castel, 2009, p.33-37, tradução livre). 
dos indivíduos) e com os tempos da Natureza (ciclos de autorregulação dos ecossistemas).

O processo de alienação é, portanto, vivenciado cotidianamente pelo trabalho, e a desalienação é parte imprescindível desse processo, é a 'incessante rebelião da atividade contra a passividade, do ser contra o sofrimento'(Holloway, 1997). É a expressão da revolta da atividade contra a sua condição estranhada (Antunes, 2002, p.41).

\section{ALIENAÇÃO DO TRABALHO: a perda da razão social e a ruptura com a natureza.}

O processo de desfiliação social (Castel, 1998) produzido pela flexibilização e precarização do trabalho (Appay; Thébaud-Mony, 1997; Hirata; Préteceille, 2002; Thébaud-Mony; Druck, 2007; Druck; Franco 2007; Bourdieu, 1998, 2001; Antunes, 2002, 2007) tem se expressado, contemporaneamente, na desvalorização da vida e na descartabilidade das pessoas, na "banalização da injustiça social" (Dejours, 1999), atingindo as identidades individual e coletiva, a dimensão ética e a dignidade humana (Seligmann-Silva, 1995, 2001, 2010, 2011). Configura, em síntese, um processo de despertencimento social, nutrido pela alienação do trabalho, que aprofunda o processo de coisificação das relações humanas, favorecendo a proliferação de diversas formas de violência social, inclusive no trabalho, sem limites de classe, gênero, etnia, idade, ramo e ocupação, etc.

A precarização do mundo do trabalho e a desregulação social em curso apontam para um processo de apagamento das noções de limites biopsicossociais - inclusive éticos -, cuja função é proteger a vida. Esse processo consolida a perda da razão social do mundo do trabalho e acentua a inversão das relações da humanidade com os limites e ciclos da Natureza.

Essa inversão em relação aos biorritmos e ciclos naturais produziu um generalizado "despertencimento" em relação à Natureza e uma barreira para que o ser humano, hoje, possa se reconhecer como "ser da espécie", um ser oriundo da natureza e dela dependente. Cotidianamen- te, os habitus no trabalho, que impregnaram a vida social - acesa, apressada e veloz-cristalizam tempos sociais incompatíveis com os biorritmos dos indivíduos, cuja ruptura se expressa em muitos adoecimentos e acidentes relacionados ao trabalho.

Esse desenraizamento em relação à Nature$z a$ se evidencia, também, na contradição entre os tempos sociais do capital e os ciclos e sistemas reguladores biológicos. Essa contradição produz o padrão predatório das relações entre as atividades humanas e o meio ambiente. Em suma, o mundo do trabalho contemporâneo aprofunda e materializa todas as dimensões do trabalho alienado. Sua configuração expressa a transformação do trabaIho alienado em trabalho patogênico; de uma sociedade alienada em sociedade patogênica.

A desalienação social passa, necessariamente, pela redefinição do sentido do trabalho - dos padrões de trabalho, com reversão do binômio flexibilização e precarização-, com o fortalecimento da razão social do trabalho. Uma razão social que seja, simultaneamente, a busca do bem viver dos homens entre si, na e com a natureza, ou seja, assentada em novos padrões de produção e consumo que, ao invés de predatórios, se ajustem à natureza e a seus ciclos.

(Recebido para publicação em 21 de fevereiro de 2011) (Aceito em 02 de maio de 2011)

\section{REFERÊNCIAS}

AKTOUF, O. A administração entre a tradição e a renovação. São Paulo: Atlas, 1996. 269p.

ALGRANTI, E.; CAPITANI, E.; BAGATIN, E. Sistema respiratório. In: MENDES, R. (Org.) Patologia do trabalho. Rio de Janeiro, Ed. Atheneu, 1995. p. 89-137.

ALTVATER, E. O preço da riqueza. São Paulo: Ed. da Universidade Estadual Paulista, 1995.

ANTUNES, R. Dimensões da precarização estrutural do trabalho. In: DRUCK, G.; FRANCO, T. A perda da razão social do trabalho: terceirização e precarização. São Paulo: Boitempo, 2007. p. 13-22.

.As novas formas de acumulação do de capital e as formas contemporâneas de estranhamento (alienação). $\mathrm{Ca}$ derno CRH: Centro de Recursos Humanos, Salvador, n.37, p.23-46, jul./dez., 2002.

. Os sentidos do trabalho. São Paulo: Boitempo, 1999. 
APPAY, B. ; THÉBAUD-MONY, A. Précarisation sociale, travail et santé. Paris: IRESCO, 1997.

BARRETO, M. L.; CARMO, E. H. Padrões de adoecimento e de morte da população brasileira: os renovados desafios para o Sistema Unico de Saúde. Ciência e Saúde Coletiva, Rio de Janeiro, v.12, p.1779-1790, supl., 2007.

.et al. Mudanças dos padrões de morbi-mortalidade: uma revisão crítica das abordagens epidemiológicas. Physis - Revista Saúde Coletiva. Rio de Janeiro, v.3, n.1, p. 127146, 1993.

BECK, Ulrich. La sociedad del riesgo: hacia uma nueva modernidad. Barcelona: Ediciones Paidós Ibérica, 1998. 303p.

BOTTOMORE, T. Dicionário do pensamento marxista. Rio de Janeiro: Jorge Zahar Ed., 2001.

BOURDIEU, P. Contrafogos: táticas para enfrentar a invasão neoliberal. Rio de Janeiro: Jorge Zahar Ed., 1998.

. Contrafogos 2: por um movimento social europeu. Rio de Janeiro: Jorge Zahar Ed., 2001.

Razões práticas: sobre a teoria da ação social. Campinas: Papirus, 1996.

Esboco de uma teoria da prática. In: ORTIZ, R. (Org.).

Pierre Bourdieu, sociologia. São Paulo: Ática, 1983. p.7-36.

O desencantamento do mundo: estruturas econô$\overline{\text { micas }}$ e estruturas temporais. São Paulo: Ed. Perspectiva, 1979. 135p.

CANÊDO, L.B. A revolução industrial. 3.ed. São Paulo; Campinas: Atual Ed./Unicamp, 1987.

CAPRA, F. O ponto de mutação. São Paulo: Cultrix, 1982.

CARELLI, R. Terceirização e intermediação de mão-deobra: ruptura do sistema trabalhista, precarização do trabalho e exclusão social. Rio de Janeiro: Renovar, 2003.

CASTEL, R. As metamorfoses da questão social. Rio de Janeiro: Vozes, 1998.

La montée des incertitudes: travail, protections, statut de l’individu. Paris: Éditions Seuil, 2009.

CHESNAIS, F. A mundialização do capital. São Paulo: Xamã, 1996.

DAMÁSIO, A. O erro de Descartes: emoção, razão, cérebro humano. São Paulo: Companhia das Letras, 1996.

DEJOURS, C. A loucura do trabalho: estudo de psicopatologia do trabalho. São Paulo: Cortez; Oboré, 1987.

Psicodinâmica do trabalho: contribuições da Escola Dejouriana à análise da relação prazer, sofrimento e trabalho. São Paulo: Atlas, 1994.

A banalização da injustiça social. Rio de Janeiro: Fundação Getúlio Vargas, 1999.

DRUCK, G. Terceirização: (des)fordizando a fábrica - um estudo do complexo petroquímico. São Paulo: Boitempo, 1999.

; FRANCO, T. A perda da razão social do trabalho: terceirização e precarização. São Paulo: Boitempo, 2007.

DURKHEIM, H. Da divisão do trabalho social. 3.ed. São Paulo: WMF Martins Fontes, 2008. 483p.

FERREIRA, C.G. Fordismo, crise e fordismo brasileiro. Caderno CESIT, Campinas, UNICAMP, n.13, 1994.

et al. Alternativas sueca, italiana e japonesa. $\mathrm{Ca}$ derno CESIT, Campinas, UNICAMP, n.4, 1994

FILGUEIRAS, L. A desestruturação do mundo do trabalho e o "mal-estar" desse fim de século. Cadernos do
CEAS, Salvador, n.171, p.9-29, set./out., 1997.

História do plano real: fundamentos, impactos e contradições. São Paulo: Boitempo, 2000.

FRANCO, T. Trabalho, riscos industriais e meio ambiente: rumo ao desenvolvimento sustentável? Salvador: CRH/ FFCH/EDUFBA/UFBA, 1997. 242p.

Trabalho alienado: habitus \& danos à saúde humana e ambientais ( $\mathrm{O}$ trabalho entre o céu, a terra e a história). 2003. Tese (Doutorado) - Universidade Federal da Bahia. Salvador: 2003.

SELIGMANN-SILVA, E. DRUCK, G. As novas relações de trabalho, o desgaste mental do trabalhador e os transtornos mentais no trabalho precarizado. Revista Brasileira de Saúde Ocupacional, São Paulo, v.35, n.122, p.229248, jul./dez.2010.

FREITAS, C. M. Acidentes químicos ampliados: incorporados a dimensão social nas análises de riscos. 1996. Tese (Doutorado) - Escola Nacional de Saúde Pública/ Fundação Oswaldo Cruz. Rio de Janeiro. 1996. 243p.

FREITAS, C.M.; PORTO, M.F.S.; MACHADO, J.M.H.. Acidentes industriais ampliados: desafios e perspectivas para o controle e a prevenção. Rio de Janeiro: Ed. Fiocruz, 2000. $316 \mathrm{p}$

GIDDENS, A.. Capitalismo e moderna teoria social: uma análise das obras de Marx, Durkheim e Weber. 3.ed. Lisboa: Ed. Presença, 1990.

GLINA, D. M. R. ROCHA, L. E. Saúde mental no trabalho: da teoria à prática. São Paulo: Roca, 2010.

GRAMSCI, A. Maquiavel. A política e o estado moderno. 5.ed. Rio de Janeiro: Civilização Brasileira, 1984. 444p. (cap.4: americanismo e fordismo, p.375-413).

HARDMAN, F.; LEONARDI, V. História da indústria e do trabalho no Brasil. 2.ed. São Paulo: Ed. Ática, 1991. 336 p.

HARVEY, D. O novo imperialismo. São Paulo: Loyola, 2004.

HIRATA, H.; PRETÉCEILLE, E. Trabalho, exclusão e precarização socioeconômica - o debate das ciências sociais na França. Caderno CRH: Centro de Recursos Humanos, Salvador, n.37, p.47-80, jul./dez. 2002.

HOBSBAWN, Eric. A era dos extremos: o breve século XX (1914-1991). São Paulo: Companhia das Letras, 1995.

Da revolução industrial inglesa ao imperialismo. Rio de Janeiro: Ed. Universitária, 1986.

JOBIN, P. Maladies industrielles et renouveau syndical au Japon. Paris: École de Hautes Études en Sciences Sociales, 2006.

KURZ, Robert. Os últimos combates. 4.ed. Petrópolis-RJ: Vozes, 1997.

O colapso da modernização: da derrocada do socialismo de caserna à crise da economia mundial. Rio de Janeiro: Paz e Terra, 1992.

LEMOS, D.V. da S. Revolução no trabalho? O caso do repensar. 2001. 216f. Dissertação (Mestrado em Ciências Sociais) - Faculdade de Filosofia e Ciências Humanas, Universidade Federal da Bahia, Salvador: 2001.

MARCUSE, Herbert. Razão e revolução: Hegel e o advento da teoria social. 5.ed. São Paulo: Paz e Terra, 2004

MARX, K. El capital. 2.ed. México: Fondo de Cultura Económica, 1959. T.1.

Manuscritos econômicos e filosóficos, primeiro manuscrito. In: FERNANDES, F. (Org.). Marx/Engels história. São Paulo: Ática, 1983. p.146-180.

Capítulo VI: inédito de o capital. Rio de Janeiro: Centauro, 2004a. 170p. 
- Manuscritos econômicos e filosóficos, primeiro manuscrito. São Paulo: Boitempo 2004b.

MERCURE, D.; SPURCK, J. O trabalho na história do pensamento ocidental. Petrópolis, RJ: Vozes, 2005.

MÉSZÁROS, I. A teoria da alienação em Marx. São Paulo: Boitempo, 2006.

MONTEIRO, C. A. (Org.). Velhos e novos males da saúde no Brasil: a evolução do país e de suas doenças. São Paulo: Hucitec/ Nupens-USP, 1995.

MORGAN, G. Imagens da organização. São Paulo: Atlas, 1996.

NAVARRO, M. et al. Doenças emergentes e reemergentes, saúde e ambiente. In: MINAYO, M. C.S.; MIRANDA, A. (Org.) Saúde e ambiente sustentável: estreitando nós. Rio de Janeiro: Ed. FIOCRUZ, 2002. p.37-49.

PASSET, R. A co-gestão de desenvolvimento econômico e da biosfera. Desenvolvimento e Meio Ambiente. Curitiba, Ed UFPR/GRLD, n.1, p.47-62, 1994.

. A ilusão neoliberal. Rio de Janeiro: Record, 2002

POSSAS, C. Epidemiologia e sociedade: heterogeneidade estrutural e saúde no Brasil. São Paulo: Hucitec, 1989.

RIGOTTO, R. M. Desenvolvimento ambiente e saúde: implicações da (des)localização industrial. Rio de Janeiro: Editora FIOCRUZ, 2008.

SELIGMANN-SILVA, E. Desgaste mental no trabalho dominado. São Paulo: Cortez, 1994.

. A síndrome da insensibilidade. In: FURTADO, T. Recursos humanos: a falência psicológica das organizações. Rio de Janeiro: Editorial Ed., 1995. p. 63-87.

Desemprego e psicopatologia da recessão. In: BORGES, L.H.; MOULIN, M.G.B.; ARAÚJO, M.D. (Org.) Organização do trabalho e saúde: múltiplas relações. Vitória: EDUFES, 2001. p. 219-254.
Trabalho e desgaste mental: o direito de ser dono de si mesmo. São Paulo: Cortez, 2011.

SENNETT, R. A corrosão do caráter: consequências pessoais do trabalho no novo capitalismo. São Paulo: Record, 1999.

SEOANI, J.; TADDEI, E. Recolonización, bienes comunes de la naturaleza y alternativas desde los pueblos. Diálogo de los Pueblos y Grupo de Estudios sobre América Latina y El Caribe (GEAL). 2010, 106 p. Disponível em: www.dialogodelospueblos.org.

SOUZA, G. A. A. de. Sucessão das gerações na Bahia: reencontro de uma totalidade esquecida. 1996. 368f. Tese (Doutorado) - Instituto de Filosofia e Ciências Humanas, Universidade Federal da Bahia. Salvador: 1996. 368f.

SPURCK, J. A noção de trabalho em Karl Marx. In: MERCURE, Daniel; SPURCK, Jan (Org.) O trabalho na história do pensamento ocidental. Petrópolis, RJ: Vozes, 2005, p. 189-211.

THÉBAUD-MONY, A.; DRUCK, G. Terceirização: a erosão dos direitos dos trabalhadores na França e no Brasil. In DRUCK, G.; FRANCO, T. A perda da razão social do trabalho: terceirização e precarização. São Paulo: Boitempo, 2007. . Travailler peut nuire gravement à votre santé. Paris: Editions La Découverte, 2007.

. L'enverz des sociétés industrielles: aproche comparative franco-brésiliènne. Paris: L’Harmatan, 1990.

VINCENT, J.M. Jürgen Habermas e o trabalho. In: MERCURE, Daniel; SPURCK, Jan (Org.) O trabalho na história do pensamento ocidental. Petrópolis: Vozes, 2005. p.259-273.

WEBER, M. A ética protestante e o espírito do capitalismo. 9.ed. São Paulo: Pioneira, 1967. 


\section{ALIENATION OF LABOR: social uprooting and unbelonging in relation to nature}

\author{
Tânia Franco
}

This essay recalls the notion of alienated labor, given its heuristic value to understand more deeply the interconnections between the fundamentals of labor and the current challenges to the social and environmental crisis. Current questions about labor lead to the approach of social precarization, loss of rights, damage to health and the environment, evidence in itself, of a profound social alienation. From a brief historical overview of urban-industrial capitalist societies which highlights the growing disagreement of social times with the cycles of nature and the plasticity or biopsychosocial limits of individuals - it is proposed to reconsider the four aspects of Marx's alienation concept. The interconnections between alienation and the Bourdieusian concept of habitus, between social precarization and environmental destruction are finally summarized in the notions of social unbelonging and uprooting in relation to nature, processes characteristic of the contemporary civilization.

KEYwORDS: alienated labor, labor and environment, work and health, precarization of work, flexibilization and social precarization.

\section{ALIÉNATIONS DU TRAVAIL: non- appartenance sociale et déracinement par rapport à la nature}

\section{Tânia Franco}

Cet essai reprend la notion de travail aliéné, vu sa valeur heuristique, pour mieux comprendre les interconnexions entre les principes fondamentaux du travail et les défis actuels de la crise sociale et environnementale. Les questions qu'on se pose actuellement à propos du travail mènent à une approche de la précarité sociale, de la perte de droits, des dommages pour la santé et pour l'environnement, preuves en soi d'une profonde aliénation sociale. À partir d'une brève rétrospective historique des sociétés urbaines et industrielles capitalistes - qui souligne un croissant désaccord entre les temps sociaux et les cycles de la nature ainsi qu'avec la plasticité ou les limites biopsychosociales des individus - on propose de revoir les quatre aspects du concept d'aliénation de Marx. Les interconnexions entre l'aliénation et le concept d'habitus de Bourdieu, entre la précarisation sociale et la destruction de l'environnement, sont finalement résumées dans les notions de nonappartenance sociale et de déracinement par rapport à la Nature, processus caractéristiques de la civilisation contemporaine.

MOTS-CLÉS: Travail aliéné, travail et environnement, travail et santé, précarisation du travail, flexibilité et précarisation sociale.

Tânia Franco - Doutora em Ciências Sociais pela Universidade Federal da Bahia. Pesquisadora do Centro de Recursos Humanos/FFCH/UFBA no campo temático do trabalho, saúde e meio ambiente. Tem graduação em Economia, Medicina e Mestrado em Ciências Sociais pela UFBA. É organizadora do livro Trabalho, riscos industriais e meio ambiente: rumo ao desenvolvimento sustentável?, (Edufba, 1997) e co-organizadora do livro A perda da razão social do trabalho: precarização e terceirização. (São Paulo: Ed. Boitempo, 2007), com artigos em periódicos diversos (Revista Brasileira de Saúde Ocupacional; Ciência \& Saúde Coletiva; Caderno CRH; RELET - Revista Latinoamericana de Estudios del Trabajo; Pistes; Laboreal). 